\title{
Industria farmazeutikoak ingurumenean duen inpaktua murrizteko estrategiak
}

\author{
(Strategies to reduce the environmental impact \\ of the pharmaceutical industry)
}

\author{
Maialen Matxain, Manoli Igartua, Rosa María Hernández, Edorta Santos-Vizcaíno*
}

Farmazia eta Elikagaien Zientziak Saila, Farmazia Fakultatea (UPV/EHU)

\begin{abstract}
LABURPENA: Industria farmazeutikoa, bere ekoizpen-bolumena kontuan izanda, gehien kutsatzen duten industriako sektoreen artean kokatzen da. Hori dela eta, lan honetan, egun martxan dagoen Nazio Batuen Erakundearen (NBE) 2030 Agendarekin lerrokatuz, eta bertan aipatzen diren helburuak betetzeko asmoz, industria farmazeutikoak ingurumenean duen inpaktua murrizteko hainbat estrategia aztertuko dira, arreta medikamentuen ekoizpenari jarriz batez ere. Lehenik, ekoizpen iraunkorra bultzatu nahian, disolbatzaile edo eszipiente organikoak fluido superkritiko eta likido ionikoen bidez ordezkatzea proposatuko da. Ondoren, medikamentu edo materia organikoek ingurune urtarrean duten bilakaera aztertuko da. Horren konponbide gisa eta baliabide hidrikoen eraginkortasuna bultzatuz, oxidazio-teknika bidezko erreakzioen erabilera proposatuko da, ur-hondakinen tratamenduan konposatu kimikoak ezabatu ahal izateko. Horrez gain, eta egungo aldaketa klimatikoak ingurumenean duen inpaktua aintzat hartuz, berotegi-efektua duten gasen isurketa murrizteko energia berriztagarrien erabilera bultzatu eta erabiltzen den energiaren efizientziaren hobekuntzarako hainbat estrategia aipatuko dira. Horretaz gain, beste zenbait etapa ere dira, medikamentua sortzen denetik medikamentua birziklatua izan arte. Hortaz, ekoizpen eta kontsumo arduratsuago baten bila, etapa horietako inpaktua ere murriztea beharrezkoa litzateke, medikamentuen kutxen diseinua aldatuz, kutxa ekologikoagoak lortzeko eta garraiorako furgoneta ekologikoen erabilera bultzatuz, besteak beste. Amaitzeko, industria farmazeutikoa I+G+b-n gehien inbertitzen duen sektorea dela aintzat hartuz, hausnarketa txiki bat egiten da, baliabide eta teknologia horiek etorkizunean ekar ditzaketen onurak azpimarratuz.
\end{abstract}

HITZ GAKOAK: Industria Farmazeutikoa, Garapen Iraunkorra, Garapen Iraunkorrerako 2030 Agenda, Ingurune-inpaktua.

\begin{abstract}
The pharmaceutical industry, in terms of the volume of production it handles, is among the most polluting industrial sectors. Therefore, in line with the current United Nations (UN) Agenda 2030, and in order to meet the objectives set out therein, in this work we will examine various strategies to reduce the environmental impact of the pharmaceutical industry, focusing especially on drug production. First, in an attempt to promote sustainable production, replacement of organic solvents or excipients with supercritical fluids and ionic liquids is proposed. Next, the evolution of drugs or organic matter in the aquatic environment will be examined. As a solution to this, and by promoting the efficiency of water resources, the use of oxidation technique-based reactions will be proposed to eliminate chemical compounds in the treatment of waste water. In addition, and taking into account the impact of current climate change on the environment, several strategies based on promoting the use of renewable energy will be analysed, in order to reduce the emission of greenhouse gases and improve the efficiency of the energy used. Additionally, other stages of the production are also examined, from the time the drug is created until the drug is discarded and recycled. Therefore, in pursuit of a more responsible production and consumption model, it would also be necessary to reduce the impact of these stages by changing the design of medicine boxes, achieving greener packaging and encouraging the use of environmentally friendly transport, among others. Finally, given that the pharmaceutical industry is the sector that invests the most in $R \& D \& I$, a small reflection is made, highlighting the benefits that these resources and technologies can bring in the future.
\end{abstract}

KEYWORDS: Pharmaceutical Industry, Sustainable Development, 2030 Agenda for Sustainable Development, Environmental Impact.

* Harremanetan jartzeko / Corresponding author: Edorta Santos-Vizcaíno. Farmazia eta Elikagaien Zientziak Saila, Unibertsitate Ibilbidea, 7 (01006 Vitoria-Gasteiz). - edorta.santos@ehu.eus - https://orcid.org/0000-0001-7064-4563

Nola aipatu / How to cite: Matxain, Maialen; Igartua, Manoli; Hernández, Rosa María; Santos-Vizcaíno, Edorta (2022). "Industria farmazeutikoak ingurumenean duen inpaktua murrizteko estrategiak». Ekaia, 42, 2022, 49-71. (https://doi.org/10.1387/ekaia.22848).

Jasotze-data: 2021, maiatzak 27; Onartze-data: 2021, uztailak 27.

ISSN 0214-9001 - elSSN 2444-3255 / (c) 2022 UPV/EHU

(i) (-) $\odot$ Lan hau Creative Commons Aitortu-EzKomertziala-LanEratorririkGabe 4.0 Nazioartekoa lizentzia baten mende dago 


\section{SARRERA}

Industria farmazeutikoa medikamentuak ekoizteaz, prestatzeaz eta merkaturatzeaz arduratzen den sektorea da, eta beraren helburu nagusien artean medikamentu berriak aurkitzea, ikertzea eta garatzea daude. Espainian, 350 enpresa farmazeutiko inguru daude, eta, gainera, hazten ari den sektorea da. Azken 15 urteetan nabarmenki igo da beraren ekoizpena. Zehazki Europan, 2000tik 2015era \% 90eko igoera izan du, eta 2015. urtean 238.000 milioi euroko balioko produktuak ekoitzi dira (1. irudia) $[1]$.

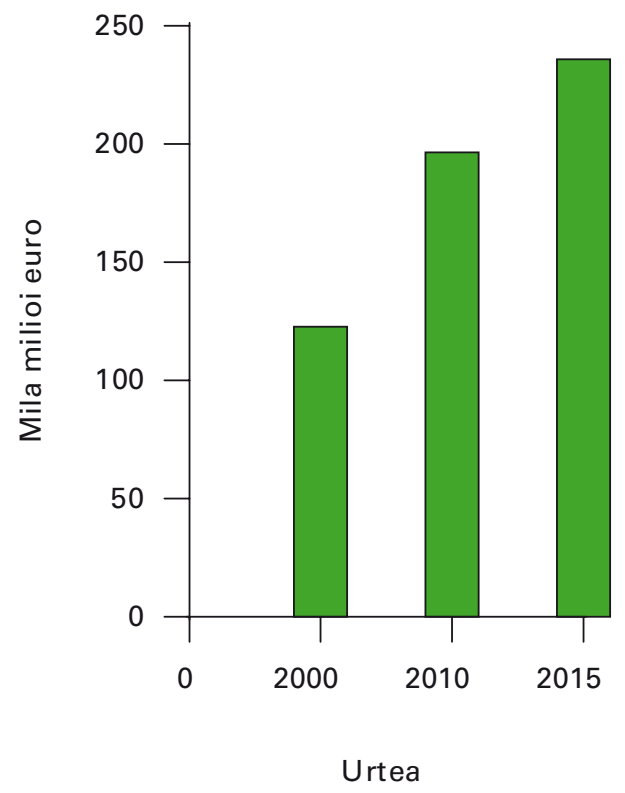

1. irudia. Industria farmazeutikoak Europan izan duen ekoizpenaren bilakaera.

Gaur egun 4.000 produktu farmazeutiko baino gehiago erabiltzen dira munduan zehar, zaintza medikorako zein albaitaritzarako. Medikamentuak eguneroko bizitzan erabiltzen ditugu beren helburu nagusia beteko dutelakoan: gaitzen sintomak arintzea edo gaixotasunak tratatzea, besteak beste. Hala ere, tamalez, gizakiongan zein ingurumenean sor dezaketen kaltea populazioak espero duena baino kezkagarriagoa da. Medikamentu hauen osagaiak zein metabolitoak, bioaktiboak eta ez-degradagarriak izanik, hainbat bideren bidez iristen dira ingurumenera, iturria medikamentuen ekoizpena izanik. Horiek horrela, ekoizpen-prozesuen zenbait hondakin farmazeutiko aurkitu dira erreketan, lur azpiko uretan, edateko uretan, lurrean... Askotan 
gainera, farmako askoren metabolitoak gernuaren bidez kanporatzen ditugu, eta ondoren hondakin-uretan agertzen dira $[2,3]$.

Zenbait ebidentzia zientifiko daude, erakusten dutenak halako hondakinen kontzentrazio apalek ere eragin nabarmenak dituztela ingurumeneko animalia zein landareen bizitzan. Horien artean aurkitzen ditugu arrain batzuek jasaten duten dimorfismo sexuala, zenbait espezie urtarren hazteko zailtasunak, etab. Horrez gain, produktu farmazeutikoen ingurumeneko esposizio hori antibiotikoekiko erresistentzien garapenarekin erlazionatzen da, eta, Nazio Batuen Erakundearen (NBE) arabera, osasun publikoko kezka handiena bilakatzen ari da (3). Horrekin batera, Health Care Without Harm-ek (ingurumeneko aztarna murrizteko asmoz mundu osoko osasuna eraldatzen lan egiten duen gobernuz kanpoko erakundea) azpimarratzen du medikamentu baten osagai aktiboak, antibiotikoenak esaterako, leku konkretu batzuetan kontzentratzen direla eta horrek farmako horien erresistentzien garapena faboratzen duela. Horrek, ondorioz, eragin larria du fabrikazio instalazioetatik eta araztegietatik gertu bizi diren biztanleen artean [4].

Gainera, McMaster unibertsitateko bi ingeniarik euren ikerketa batean azaldu zuten industria farmazeutikoak automobilgintzak baino gehiago kutsatzen duela gaur egun. Zehazki, \% 13 karbono gehiago isurtzen dutela adierazten zuten, nahiz eta industria farmazeutikoaren merkatua automobilgintzarena baino \% 28 txikiagoa izan [5]. Hori guztia dela eta, industria farmazeutikoaren helburu nagusia ingurumenarentzat ahalik eta kalte gutxien sortzen duten produktuak sortzea litzateke. Horretarako, 2016an indarrean jarritako Garapen Iraunkorrerako 2030 Agenda har daiteke bide-orri gisa. Bertan 17 helburu barneratzen dira (garapen iraunkorraren helburuak, GIH); beste lehentasun batzuen artean, klima-aldaketa, desparekotasun ekonomikoa, berrikuntza, kontsumo iraunkorra, bakea eta justizia aurki ditzakegu [6].

Artikulu honetan, industria farmazeutikoak ingurumenean sortzen duen inpaktua murrizteko hainbat estrategia posible deskribatzen dira, batez ere medikamentuen ekoizpenean, biltegiratzean eta garraiatze-prozesuen kontrolean ardaztuz. Gainera, estrategia horiek 2030 Agendan aipatzen diren honako helburu hauekin lerrokatuko lirateke: (6. GIH) uraren erabilgarritasuna eta kudeaketa iraunkorra nahiz guztiontzako saneamendua bermatzea; (7. GIIH) energia eskuragarria, fidagarria, iraunkorra eta modernoa bermatzea; (12. GIH) kontsumo- eta ekoizpen-modalitate iraunkorra bermatzea; (15. GIH) lehorreko bizitza babestea, lehengoratzea eta modu iraunkorrean.

\section{INGURUNE-INPAKTUA MURRIZTEKO ESTRATEGIAK}

Azkenaldian, geroz eta kontzientzia handiagoa dago garapen iraunkorraren inguruan. Garapen iraunkorra lortzeko asmoz, Nazio Batuen Era- 
Maialen Matxain, Manoli Igartua, Rosa María Hernández, Edorta Santos-Vizcaíno

kundeak 2030 Agenda kaleratu zuen. Agenda hori pertsonen, planetaren eta oparotasunaren aldeko ekintza-plana da, eta helburu du, besteak beste, gure planeta babestea. Guztira 17 helburuk eta 169 erronkak osatzen dute, eta helburu zein erronka horiek integratuak eta banaezinak dira, eta garapen iraunkorraren hiru dimentsioak batzen dituzte: ekonomikoa, soziala eta ingurumenekoa. Hori dela eta, artikulu honetan ingurumena babestearen alde jarduten duten helburuak aipatzen dira, helburu horien harira egin daitezkeen ekintzak aipatuz. Hau da, industria farmazeutikoak helburu horietako batzuk erdiesteko hainbat balizko estrategia deskribatuko dira.

\subsection{Disolbatzaile eta eszipiente organikoen ordezkatzea}

9 EKOIZPENETA

KONTSUMO

ARDURATSUA

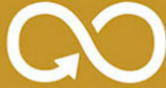

\subsection{Kontsumo eta ekoizpen arduratsurako egitasmoak}

2030 Agendaren helburuetako bat ekoizpen eta kontsumo iraunkorrean datza, eta horrek barne hartzen du hondakinen sorrera murriztea, halakoek ingurunean zein giza osasunean eragiten dituzten kalteak arintze aldera. Hori dela eta, medikamentuen ekoizpenean erabiltzen diren produktuek garrantzi handia dute. Egun, kimikaren helburuetako bat beharrezkoak ez diren osagaiak saihestea edo murriztea da; hau da, arriskutsuak izan daitezkeen substantzien murrizketa ahalbidetzen duten produktu eta prozesu kimikoen diseinuan datza. Horretarako, teknologiaz baliatuz, disolbatzaile konbentzionalen kantitateak murriztea lortzen da, zeinak hondakinen kantitate esanguratsu batekin erlazionatzen baitira [7, 8].

Industria farmazeutikoan etengabe erabiltzen dira disolbatzaile organikoak; erreakzio kimiko baten masaren \% 80-90 izan daitezke [7]. Gainera, barrera fisiko-kimikoak tarteko, askotan ezin izaten dira guztiz ezabatu azken produktuetatik, eta, bertan geratzen direnez, garraioan, bilketan eta abarretan kutsakorrak izan daitezke. Hondakin horiei hondakin-disolbatzaile deitzen zaie, nahiz eta disolbatzaile organiko lurrunkor izena ere ematen zaien. Arriskuaren arabera lau talde bereizten dira, eta, horien artean, lehen taldekoak dira kalte larrienak eragiten dituztenak, kartzinogenoak izanik gizakietan. Talde horren barnean daukagu 1,1,1-trikloroetanoa, zeina ingurumenarentzat kaltegarria baita (izan ere, eguzki-izpiek degradatu egin dezakete, eta ozono geruza suntsitzen duten molekula bihurtu). Ez hori bakarrik: ingurumenean 6 urte ere iraun dezake; beraz, eragindako kalteak denbora luzez mantentzen dira. Hortaz, halakoak ahal den guztietan saihestu egin behar dira. Bigarren taldeko disolbatzaileek, aldiz, behintzat murriztuak izan behar dute; izan ere, animalietan kartzinogeno ez-genotoxikoak dira, eta toxikotasun itzulezina eragiten dute (1. taula). Hirugarren taldekoak toxikotasun eta arrisku txikiagoa dute gizakiengan. Hala ere, ez dago epe luzeko toxikotasun- zein kartzinogenesi-azterketarik eginda. Azkenik, laugarren taldean sartzen dira toxikotasun-azterketarik ez dutenak, 
eta ez da ezarri haien erabilerarako mugarik [9-11]. Halako disolbatzaileetatik gehien erabiltzen direnak bigarren taldekoak dira, toluenoa izanik produktuetan gehien erabiltzen den disolbatzaile organikoa [12].

1. taula. Disolbatzaile organiko batzuk taldetan antolatuta.

\begin{tabular}{|c|c|c|}
\hline Taldea & Disolbatzaile organikoak & Ezaugarriak \\
\hline \multirow{5}{*}{$\begin{array}{c}1 . \\
\text { TALDEA }\end{array}$} & Bentzenoa & \multirow{5}{*}{$\begin{array}{l}\text { - Kaltegarrienak. } \\
\text { - Kartzinogenoak. }\end{array}$} \\
\hline & Karbono tetrakloruroa & \\
\hline & 1,2-dikloroetanoa & \\
\hline & 1,1-dikloroetanoa & \\
\hline & 1,1,1-trikloroetanoa & \\
\hline \multirow{5}{*}{$\begin{array}{l}2 . \\
\text { TALDEA }\end{array}$} & Kloroformoa & \multirow{5}{*}{$\begin{array}{l}\text { - Animalietan kartzinogeno ez-genotoxikoak. } \\
\text { - Toxikotasun itzulezina. }\end{array}$} \\
\hline & Diklorometanoa & \\
\hline & Hexanoa & \\
\hline & Metanola & \\
\hline & Toluenoa & \\
\hline \multirow{5}{*}{$\begin{array}{l}3 . \\
\text { TALDEA }\end{array}$} & Azido azetikoa & \multirow{5}{*}{$\begin{array}{l}\text { - Ez dago epe luzeko toxikotasun- eta kartzino- } \\
\text { genesi-azterketarik. } \\
\text { - Erabilienak. }\end{array}$} \\
\hline & Azetona & \\
\hline & Etanola & \\
\hline & Etil azetatoa & \\
\hline & 1-propanola & \\
\hline \multirow{5}{*}{$\begin{array}{l}4 . \\
\text { TALDEA }\end{array}$} & 2,2-dimetoxipropanoa & \multirow[t]{5}{*}{ - Toxikotasun-azterketarik ez. } \\
\hline & Isoheptanoa & \\
\hline & Isooktanoa & \\
\hline & Azido trikloroazetikoa & \\
\hline & Azido trifluoroazetikoa & \\
\hline
\end{tabular}

Toxikotasun-arazoak direla eta, hondakin-disolbatzaileen kantitatea murriztera jotzen dute fabrikatzaileek. Eragin terapeutikorik ez dute eta hondakin gisa deuseztatzen dira edo ingurunera botatzen dira. Gainera, horietatik gehienak zuzenki edo zeharka petroliotik eratorriak dira. Horrez 
gain, disolbatzaile hauek inhalatzeak ere arazo latzak ekar ditzake, deskribaturiko zenbait kasutan entzefalopatia eragin baitute $[7,12,13]$.

Hori guztia dela eta, oso garrantzitsua da disolbatzaile organiko hauen kantitatea murriztea edo ordezkoak bilatzea. Gainera, egun kimika berdearen helburua kimika garbiago eta iraunkorrago bat eraikitzea da, ingurumenarekin bateragarriagoak diren prozesuak eta teknologiak diseinatuz. Horren eredu dira fluido superkritikoak zein likido ionikoak.

\subsubsection{Likido ionikoak (IL)}

Likido ionikoak fusio-puntua $373 \mathrm{~K}$-ren azpitik duten gatzez osatutako azpimultzoak dira, katioi organikoz eta anioi organiko zein inorganikoz osatuak (2. irudia). Zenbait abantaila dituzte disolbatzaile konbentzionalen aurrean: garrantzitsuena, lurrun-presio baxua izatea; izan ere, ezaugarri horri esker ez lurrunkorrak dira, eta atmosferara gutxiago isurtzen dira. Horrez gain, likido hauen izaera kationiko edo anionikoak disolbagarritasuna zehazten du, eta disolbagarritasun ona erakusten dute ingurune organiko zein inorganikoetan. Bestalde, ez dira sukoiak; disolbatzaile konbentzionalen antzeko biskositatea dute; kimikoki egonkortasun ona erakusten dute, eta, beraz, berrerabili egin daitezke. Ondorioz, egun etorkizuneko disolbatzaile edo disolbatzaile berde deritze $[14,15]$.

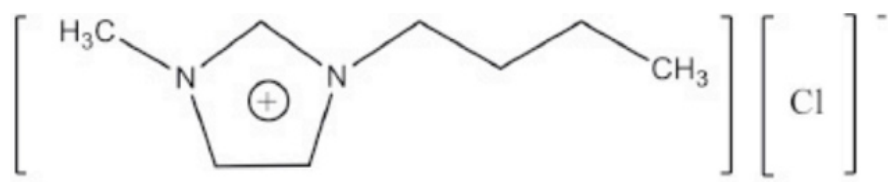

1-butil-3-metilimidazolio kloruroa

2. irudia. IL-aren eredua [16].

IL-ak kimika berdean duten aplikazioari dagokionez, disolbagarritasunahalmena dela eta, disolbatzaile gisa erabiltzen dira, baina katalizatzaile gisa ere paper garrantzitsua dute. Katalizatzaile edo ko-katalizatzaile gisa erreakzioaren abiadura azkartu, etekina handitu edo selektibitatea aldatzen dute [15].

\subsubsection{Fluido superkritikoak (FSC)}

FSCak presio eta tenperatura kritiko jakin batetik gorako baldintzetan dauden substantziak dira, likido eta gasen arteko ezaugarriak hartzen dituztenak (3. irudia). 


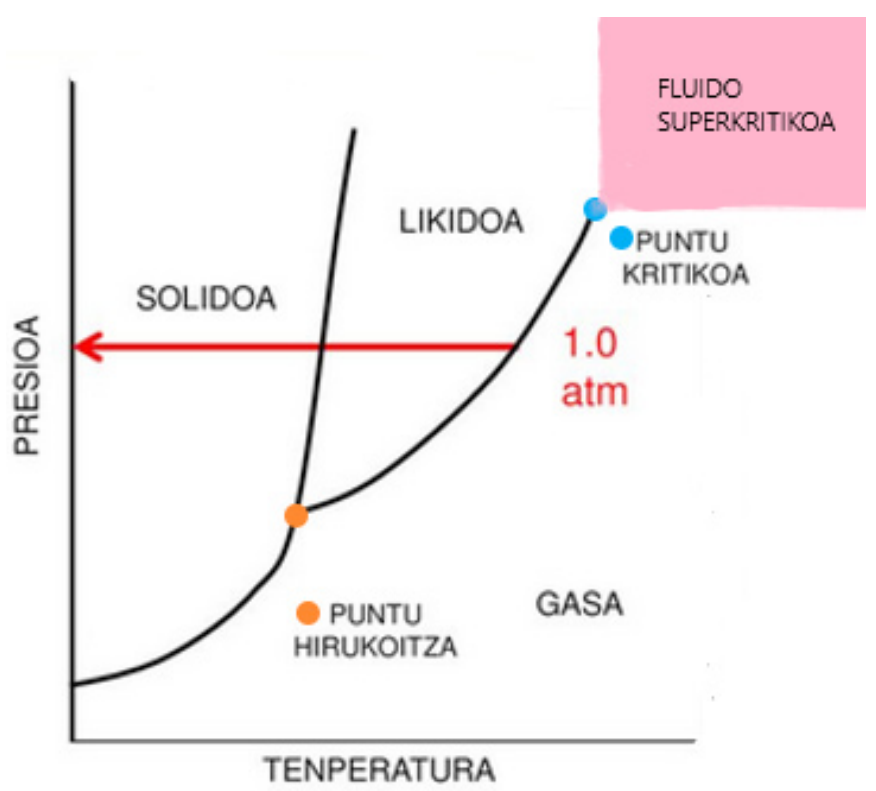

3. irudia. Fluido superkritikoen diagrama.

FSCaren dentsitatea likido baten berdina da, eta, aldiz, gasen antzeko biskositatea eta hedatze-ahalmena ditu. Hori dela eta, tenperaturarekin zein presioarekin jokatuz, ezaugarri horiek aldatu egin daitezke, hainbat prozesuetan zenbait abantaila erakusteko. Gainera, FSC askok tenperatura kritiko baxua dute, erauzketarako abantaila bat izanik. Izan ere, tenperatura baxuetan egindako erauzketetan, ezegonkortasun termikoa saihesten dugu. FSCen garraiatze-ahalmena likidoena baino handiagoa da, biskositate baxuari eta hedatze-ahalmen handiari esker. Horiek horrela, material solidoetan errazago barreia daitezke, eta, hala, erauzketa azkarrago eta eraginkorragoak lortu, hau da, hondakin gutxiago sortu [7].

FSC gehienak egokiak izan arren, gehien erabiltzen dena karbono dioxido superkritikoa $\left(\mathrm{scCO}_{2}\right)$ da. Beraren tenperatura kritikoa $304,1 \mathrm{~K}$ $\left(31,1^{\circ} \mathrm{C}\right)$ da, eta presio kritikoa 73,8 bar, balio horiek lortzea erraza izanik. Tenperatura kritikoa baxua denez, erauzketa tenperatura baxuetan egitea ahalbidetzen du, eta horrek garrantzi handia du osagai termolabilak daudenean. Horrez gain, $\mathrm{scCO}_{2}$-a ez da toxikoa, merkea da, substantzia askoren aurrean inertea da, ez da sukoia, eta presioa gutxitze hutsarekin ezaba daiteke produktuetatik. Sintesirako abantaila bat erakusten du: purua da, eta, hortaz, kantitate gutxiago behar da [7]. 
Maialen Matxain, Manoli Igartua, Rosa María Hernández, Edorta Santos-Vizcaíno

\subsection{Oxidazio bidezko uraren tratamendua}

R EDATEKOURA

(1) ETASANEAMENDUA

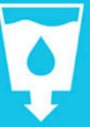

\subsection{Kalitatezko ura. Kontaminazioa eta hondakin-urak}

\subsection{Baliabide hidrikoen erabilera efizientea}

2030 Agendaren helburu nagusietariko bat da uraren erabilgarritasuna eta kudeaketa iraunkorra nahiz guztiontzako saneamendua bermatzea. Horren harira, gainditu beharreko erronka garrantzitsua da uraren kalitatea hobetzea. Horretarako, mugarri hauek erdietsi behar dira mundu osoan: kutsadura murrizteko hondakinik, produktu kimikorik eta material arriskutsurik ez isurtzea eta tratatu gabeko hondakin-uren ehunekoa erdira murriztea. 2030 Agendan uraren kalitatearekin erlazionatuta dagoen helburu bati ere egiten zaio erreferentzia 2030 Agendan, itsaspeko bizitzari zehazki. Hortaz, berebiziko garrantzia dauka uraren tratamendu egokia egiteak (6). Gainera, uraren tratamendu ezegokiak osasunarentzat zein ingurumenarentzat arazo larri bihurtzen ari dira munduan zehar. Industriak, eskuragarri dagoen uraren \% 5-20 kontsumitzen du, eta industria farmazeutikoa, beste zenbait industriarekin batera, efluente kontaminatzaile gehien sortzen duen sektorea da [17].

Uraren GIHk barne hartzen du honako erronka hau: hemendik 2030era, nabarmen areagotzea baliabide hidrikoen erabilera eraginkorra sektore guztietan. Beraz, helburu horren harira eta arazo horiek guztiak ekiditeko, hondakin-uren tratamendua ongi burutzea funtsezko bilakatzen da. Tratamendua ez bada ongi egiten, farmakoak zein haien metabolitoak ingurune urtarretara irits daitezke, bai itsasoetara bai edateko uretara. Gainera, egungo uren tratamendu konbentzionalek (klorazioak, besteak beste) konposatu horien \% 50 soilik deusezta ditzakete. Bestalde, beste zenbait tratamendu aurreratuk, oxidazioa horien artean, eraginkortasun ia guztizkoa erakutsi dute: produktu farmazeutikoen \% 99 baino gehiago ezabatzera iristen dira [18]. Hala ere, kostu handiko teknologiak dira eskala industrialera eramateko, eta, hortaz, konposatu baten oxidazio osoa burutu beharrean, oxidazio partziala egitea proposatzen da. Horrela, toxikotasun baxuagoa eta biodegradagarritasun handiagoa duten konposatuak lortzen dira, alegia, ondoren sistema biologiko konbentzionalen bidez ezaba daitezkeenak [19].

\subsubsection{Oxidazio prozesu aurreratuak (POA)}

Hondakin-uren arazketa-prozesuak ondorengo etapez osatuta egoten dira: aurretratamendua, lehen mailako tratamendua eta bigarren mailako tratamendua. Hala ere, zenbaitetan hirugarren mailako tratamenduak ezartzen dira, araztutako ura berrerabiltzeko helburuarekin. POA horiek hirugarren mailako tratamenduan jarduten dute, eta zailki biodegradagarriak 
diren konposatuak zein kontaminazio mikrobiologikoa gutxiagotzen dute. Gainera, kontaminatzaile ugari oxidatzeko gaitasuna dute, eta, prozesua behar bezainbeste luzatuz gero, mineralizaziora (material organikoa, inorganiko bihurtzeko prozesua) irits daitezke. Bestalde, oxidazio maila erdian geratzea ere posible da, kasu honetan proposatzen den moduan, ondoren beste garbiketa metodo batekin egokitzeko, prozesu biologikoekin hain zuzen ere [20].

Zenbait teknologia daude, baina denek prozesu fisiko-kimiko bat egiten dute, kontaminatzaileen estrukturan aldaketa sakon bat eragiteko asmoz. Izan ere, burdinatik edo oxigenotik abiatuta, hidroxilo erradikala sortzen dute, eta horrek, erredox potentzial handia izanik, kontaminatzaile organiko zein inorganikoak suntsitzeko gaitasuna du (4. irudia). Horiek horrela, oxigenoaren eskaera kimikoa (chemical oxygen demand COD), karbono organiko totala edo (total organic carbon, TOC) eta tratatutako ur-hondakinen kutsadura murrizten dute $[17,20]$.

$$
\mathrm{Fe}^{2+}+\mathrm{H}_{2} \mathrm{O}_{2} \rightarrow \mathrm{Fe}^{3+}+\mathrm{HO} \bullet+\mathrm{OH}^{-}
$$

4. irudia. Oxigenazio-prozesu aurreratuak ( $\mathrm{POA})$ hidroxilo erradikalak sortzeko burutzen duen erreakzioa [20].

Prozesu ohikoenak Fenton eta haren deribatua den Foto-Fenton prozesuak dira. Fenton prozesuak zenbait konposatu organikoren oxidaziorako erabiltzen dira, burdina-gatzen bidez, $\mathrm{H}_{2} \mathrm{O}_{2}$-aren deskonposizioa eraginez ingurune azidoan (5. irudia). Oxidazio-sistema erakargarria da; izan ere, burdina ugari dagoen elementua da, eta ez da toxikoa. Horrez gain, $\mathrm{H}_{2} \mathrm{O}_{2}$ erraz maneiatzen da, eta ez du ingurumenean kalterik eragiten [20].

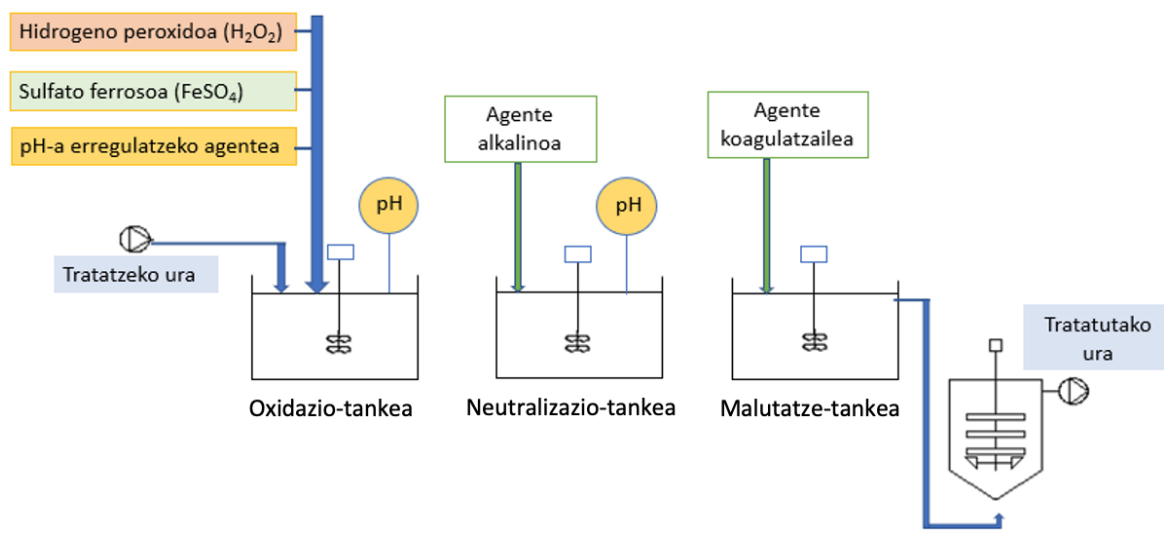

5. irudia. Fenton prozesuaren eskema. 
Maialen Matxain, Manoli Igartua, Rosa María Hernández, Edorta Santos-Vizcaíno

Hala ere, Fenton prozesu honek hobekuntza bat izan dezake argia igortzen bazaio; foto-Fenton deritzo prozesu horri. Argi ultramoreak prozesuaren eraginkortasuna hobetzen du, hidroxilo erradikal gehiago sortzen baititu. Horiek horrela, eraginkortasuna hobetzearen ondorioz, foto-Fenton prozesuak etekina hobetzen du: beharrezko erreaktiboen kantitatea murriztu, eta gastua txikitu [20].

\subsection{Energia berriztagarrien erabilera eta efizientzia energetikoaren hobekuntza}

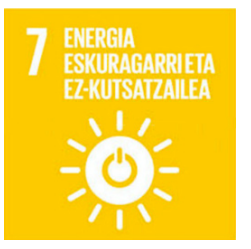

7.2. Energia berriztagarriak

\subsection{Efizientzia energetikoa}

Klima-aldaketa gai kezkagarria da, eta berebiziko premia du egoerari aurre egiteko neurriak hartzeak. NBEk berak garapen iraunkorrerako agendan klima-aldaketa eta haren efektuak geldiaraztea du helburutzat. Hala ere, tenperatura-aldaketa ez da sortu den kezka bakarra. Izan ere, beroketa globalaz gain, energiaren erabilerarekin erlazionatutako hainbat arazo daude, hala nola airearen kutsadura, euri azidoa, ozonoaren zulatzea, basoen suntsiketa eta substantzia erradioaktiboen igorpena, besteak beste. Horrek ekosistemetan hainbat aldaketa eragin ditu: itsasoaren ur maila igotzen ari da eta glaziarrak gutxitzen; animalia zein landareen banaketa aldatzen ari da; landareak sasoia heldu baino lehen loratzen dira, eta beste hainbat. Zientzialarien esanetan, tenperaturaren igoera eta horrek dakartzan eraginak berotegi-efektuaren ondorio dira. Izan ere, eguzki-energia Lurrera iristean, energia horren zati batek Lurra berotzen du eta beste zatia atmosferara igortzen da. Han, ur-lurrunak, karbono dioxidoak, metanoak eta nitrogeno oxidoak bero hori xurgatu eta lurrean islatzen dute berriz, Lurrari berotasuna ematen dion gurpil-zoro bat sortuz [21].

Egun berotegi-efektua duten gasen isurtzea historiako maila altuenean dago. Beraz, neurriak hartu ezean, munduko gainazaleko batezbesteko tenperatura 3 gradu zentigradu handituko litzateke mende honetan. Gainera, 1990etik hona karbono dioxidoaren isurtzea \% 50 handitu da; 2000. eta 2010. urteen bitartean isuritako gas kantitatea, azken 3 hamarkadetan, 30 urteetan, isuri dena baino handiagoa izan da. Txinako industria farmazeutikoan egindako ikerketa batean ere ikusi da 2000tik 2016ra $\mathrm{CO}_{2}$-aren isurtzea 23,03 Mt-tik 55,34 Mt-ra igo dela [22, 23].

Isuritako berotegi-efektudun gasen mailak gora egiten jarraitzen badu, gainazaleko tenperatura igo, eta horrek aldaketa itzulezin eta katastrofikoak eragingo ditu ingurumenean. Hori horrela izanik, nazio guztien erronka, industrializatuena batik bat, $\mathrm{CO}_{2}$-aren isurketa 2050erako \% 50-80 jaistea da; izan ere, $\mathrm{CO}_{2}$ gasa da beroketa horren erantzule nagusia. Horretarako, 
2030 Agendak energia eskuragarria, fidagarria, iraunkorra eta modernoa guztiontzat bermatzea du helburutzat. Horretarako, energia berriztagarrien erabilera bultzatu eta efikazia energetikoa hobetzea da [24, 25].

\subsubsection{Energia berriztagarrien erabilera}

Energia berriztagarriak etengabe berritzen diren eta agorrezinak diren fenomeno naturaletatik eratorritako energiak dira. Hau da, fenomeno naturalak (eguzki-argia, olatuak, haizea, landareen hazkuntza, etab.) energia bihurtzen dituzte. Horrela, badira hainbat energia berriztagarri mota, hala nola eguzki-energia, eolikoa, geotermikoa, hidraulikoa edo biomasa, besteak beste. Energia hori erabilgarri bihurtzean, erregai fosilek eskaintzen duten pareko potentziala lortzen dute [22].

Energia berriztagarrien artean eguzki-energia dugu. Eguzkitik datorren energia aprobetxatzen du, eta Eguzkia, energia igortzen 5 mila milioi urte daramatzan arren, ez da iritsi oraindik bere existentziaren \% 50era. Gainera, energia berriztagarria izateaz gain, energia garbia da, eta bestelako energia ez-berriztagarrien ordezko egokia izan daiteke [26].

Hiru eguzki-energia mota daude: eguzki-energia fotovoltaikoa, eguzkienergia termikoa eta eguzki-energia pasiboa. Fotovoltaikoan, eguzki-erradiazioa korronte elektriko bihurtzen da, eta korronte elektriko hori instalazioan elektrizitatea sortzeko erabiltzen da. Eguzki-energia termikoa berriz, eguzki-kolektorearen bidez ura berotzeko erabiltzen da, berogailuetan adibidez. Azkenik, eguzki-energia pasiboa eraikuntzaren orientazioaz, kokaguneaz eta diseinu arkitektonikoaz baliatzen da, eguzki-energia aprobetxatzeko [26].

\subsubsection{Arrakasta izan duten kasuak}

Kataluniako Alcon laborategiak Bikaintasun Energetikoaren Saria jaso zuen, energiaren aurreztea eta energia berriztagarrien erabilera azpimarratuz 2010ean. El Mansou-n duten ekoizpen-instalazioan, 2.132 eguzki-panel fotovoltaiko kokatu zituzten eraikinetako estalkietan, eta urteko $326.000 \mathrm{~kW}$ baino gehiago sortzen dute (6. irudia). Horrela, berotegiefektua eragiten duten gasen isurketa murriztea espero dute, zehazki, $126 \mathrm{Tn} \mathrm{CO}_{2}$ /urteko. Bestalde, 2014an eguzki-energia termikoa erabiltzen hasi ziren ura berotzeko, eta 2015ean, berriz, ibilgailu elektrikoak kargatzeko zerbitzua jarri zuten martxan. Hori guztia dela eta, 2009 eta 2014 urteen bitartean kontsumo elektrikoa \% 24 murriztea lortu dute, produkzioa $\% 21$ handitu arren. Horrez gain, 2008tik 2015era bitartean, ontziratutako 100 unitateko, kontsumitutako energia $22 \mathrm{kWh}$-tik $13 \mathrm{kWh}$-ra jaitsi da $[25,27]$. 
Maialen Matxain, Manoli Igartua, Rosa María Hernández, Edorta Santos-Vizcaíno

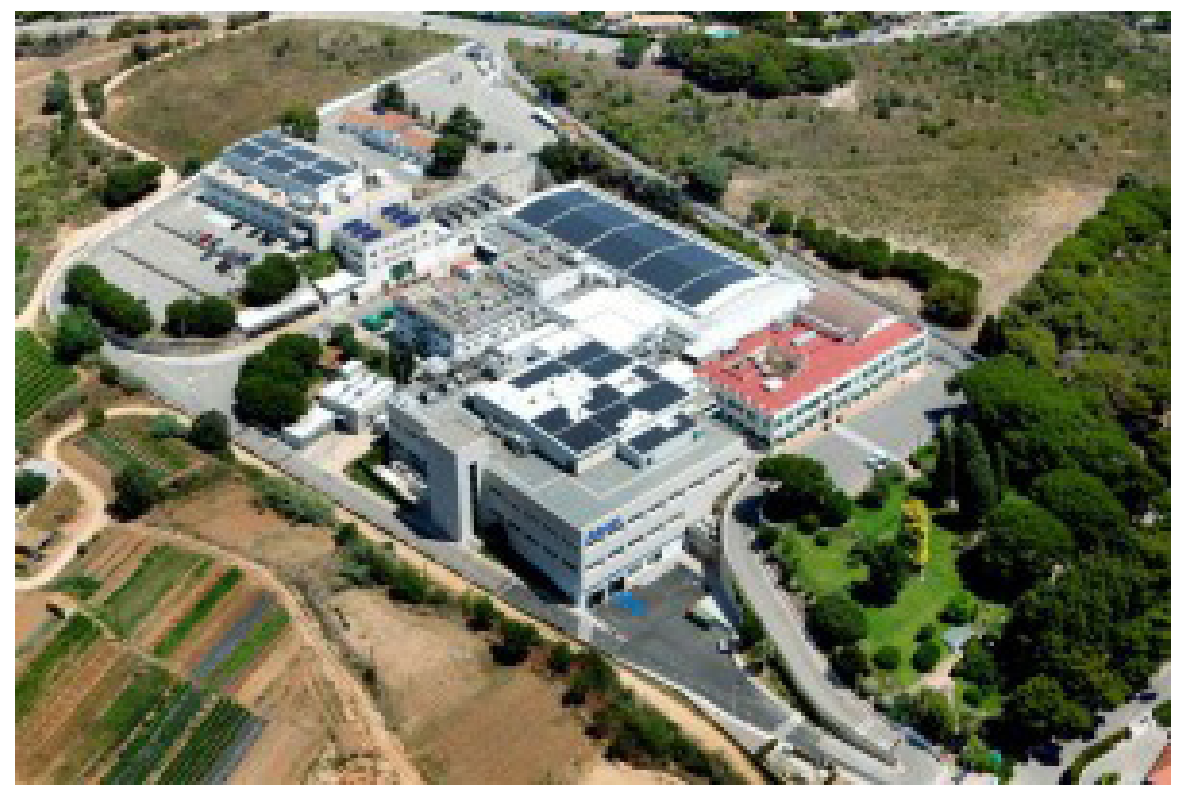

6. irudia. Alcon-ek El Masnou-n duen ekoizpen-instalazioa [28].

Almirall konpainia farmazeutiko kataluniarrak ere instalazio fotovoltaiko bat ezarri du, 6.822 eguzki-panel kokatuz eraikinaren estalkian, aparkalekuan eta esparruari erantsitako eremu batean. Horren bidez sortzen den energia berriztagarria Sant Andreu plantak kontsumituko du, bere behar elektrikoaren \% 12 hornitzeraino. Beraren potentzia $800 \mathrm{kWp}$-koa da, eta urteko $1.200 \mathrm{kWh}$ aurrezteko esperantza du, atmosferara 479 tona $\mathrm{CO}_{2}$ gutxiago isuriz. Hala ere, teknologia honez gain beste zenbait teknologia berritzaile ere inplementatu ditu (lebitazio magnetikoa horien artean). Horrela, 2012tik 2018ra bitartean bere elektrizitatearen zein gasaren kontsumoa \% 18 hobetu du [29].

\subsubsection{Efizientzia energetikoaren hobekuntza}

Industria farmazeutikoak energia kontsumo handia du. Hori dela eta, oso garrantzitsua da fabrikazio-prozesuetan erabiltzen den energia horren efizientzia optimoa izatea.

\subsubsection{Motor elektrikoen kalitatea}

Industria farmazeutikoan hainbat motor daude klimatizazio-sistemako zein laborategiko zenbait ekipotan, hala nola nahasgailuak, bonbak, lehor- 
gailuak edo zentrifugagailuak. Hori dela eta, zaharrak geratzen ari diren motorrak berriagoak diren eta eraginkortasun handiagoa duten motor batzuez ordezkatuz, energiaren \% 5-20 aurreztu daiteke. Horrez gain, oso garrantzitsua da motor horien mantentze-lanak eguneratuta eramatea, horrela motor-sistemak erabiltzen duen energiaren $\% 2$ eta $\% 30$ bitartean aurreztu baitaiteke [30].

Kontuan izan behar da baita ere motorraren tamaina, zeren tamaina handiko motorrak txikiago batzuez ordezkatuz elektrizitatearen kontsumoa $\% 1,2$ murriztu daiteke [30,31].

\subsubsection{Kogenerazioaren erabilera}

Kogenerazioa, energia termikoa eta elektrizitatea aldi berean sortzen dituen prozesua da. Teknologia horrek zenbait sistema konbinatu erabiltzeko aukera ematen du; esaterako, beroa eta energia barne hartzen dituen sistema (CHP). Hori horrela izanik, abantaila handi bat eskaintzen digu: sistema konbinatuarekin eraginkortasuna \% 90 handitzera irits daiteke. Gainera, sistema horrek sortzen duen bero hori ura eta ingurua berotzeko erabil daiteke; hala, ekonomikoki onuragarriago litzateke, elektrizitatea soilik sortzen duten sistema konbentzionalen aurrean. Izan ere, energia termiko zein elektrikoa aldi berean ekoiztearen ondorioz, energia kantitate handi bat aurreztera irits gaitezke. Ondorioz, egun elektrizitatea sortzeko eraginkortasun handiko sistema da (7. irudia) [24].

\section{Kogenerazio sistema}
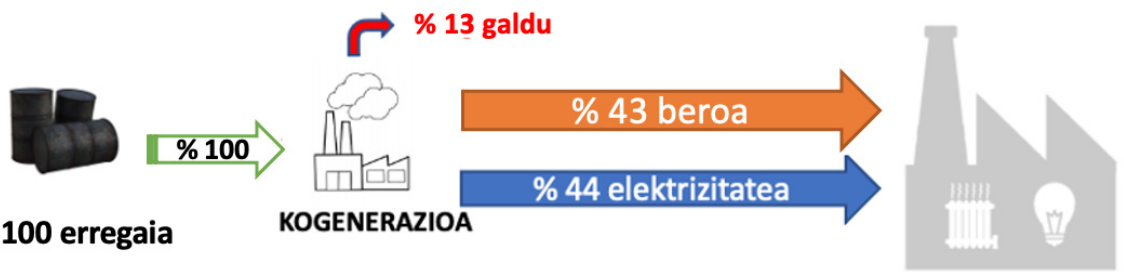

\section{Beroa eta elektrizitatea bananduta sortzen duten sistemak}

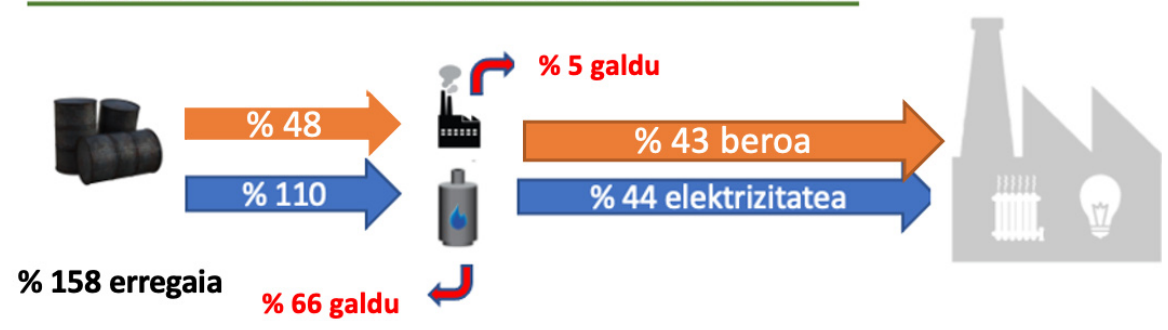

7. irudia. Kogenerazio-sistemak beroa eta elektrizitatea bananduta sortzen duten sistemen aurrean aurrezten duen energia kantitatea. 
Horrez gain, beroa eta elektrizitatea bananduta ekoizten duten erregai fosilekin alderatzen badugu, CHPrekin etekin berdina lortzeko behar dugun erregai kopurua nabarmenki murrizten da. Hori dela eta, kogeneraziosistemaren bidez sortzen den energia elektrikoak berotegi-efektua duten gasen isurketa minimoa eragingo du, ingurumenari onura garrantzitsu bat ekarriz [24].

\subsubsection{Argiztapena}

Industria farmazeutikoan argia funtsezkoa da, eta, lan honetan, egun merkaturatuta dauden bi lanpararen arteko konparazioa da, zehazki LED teknologiako eta halogenuro metalikozko (HM) lanparena (8. irudia).

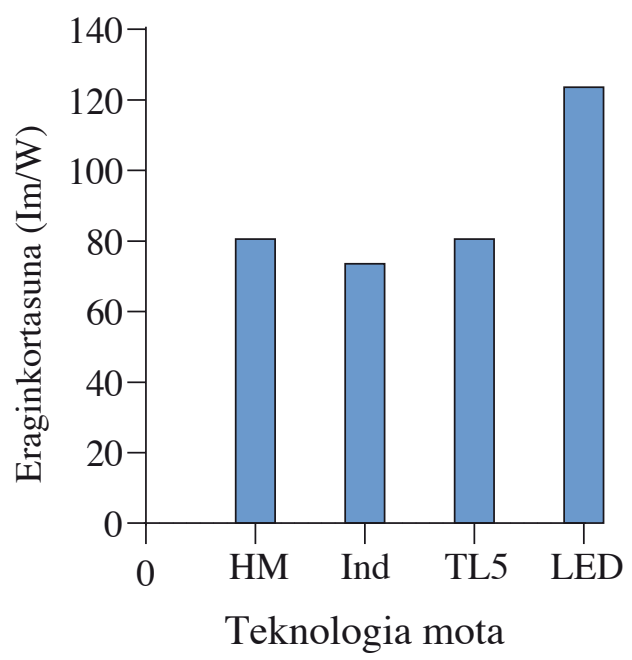

8. irudia. Egun komertzializatuta dauden teknologien arteko eraginkortasunaren konparazioa: HM, indukzio bidezko fluoreszentzia, hodi bidezko fluoreszentzia (TL5) eta LED [32].

Grafikoan ikusten den bezala (8. irudia), LED lanparek besteen aldean energia-eraginkortasun nabarmen handiagoa dute. Horrez gain, HM $400 \mathrm{~W}$-eko lanparak LED erako $200 \mathrm{~W}$-eko lanpararen potentzia berdina duela egiaztatu da. Horrela, biak 5.280 ordu pizturik egonda, \% 50eko energia-aurrezpena izango genuke (2. taula) [32].

Ondorioz, $400 \mathrm{~W}$-eko HM lanparak $200 \mathrm{~W}$-ko LED lanparaz ordezkatzea energia aurrezteko estrategia bat izan daiteke. Izan ere, LED teknologiaren erabilerak energia elektrikoaren \% 45eko aurrezpena ekar dezake, 
zehazki funtzionamenduan daudela $85,28 \mathrm{~g} \mathrm{CO}_{2}$ /ordu gutxiago isurtzeko adina energia [32].

2. taula. MH $400 \mathrm{~W}$ LED $200 \mathrm{~W}$-ez ordezkatuz lortuko genukeen energiaren aurrezpenaren kalkulua.

\begin{tabular}{lcccccc}
\hline \multicolumn{1}{c}{ Argia } & $\mathrm{P}(\mathrm{W})$ & Ordua/egun & $\mathrm{kW}$ h/egun & Lanegunak & Orduak/urtean & $\mathrm{KW}$ h/urte \\
\hline MH40 & 428 & 24 & 10,27 & 220 & 5.280 & $2.259,8$ \\
LED200W & 220 & 24 & 5,28 & 220 & 5.280 & $1.161,6$ \\
\hline
\end{tabular}

\subsubsection{Sistemaren kudeaketa}

Instalazioen kudeaketak ere garrantzia dauka energia aurrezteko orduan. Enpresa ekoizpen-prozesuan ez dagoenean tenperaturarekin joka dezakegu (adibidez, udan tenperatura igoz eta neguan jaitsiz), klimatizazio sistemek egin beharreko lana gutxitzeko. Horrez gain, produkziorik ez dagoenean, laborategiko aireztapen-sistemak murriztuz edo itzaliz ere, energia aurreztu genezake. Hori guztia dela eta, sistemaren kudeaketa egoki baten bidez, energiaren \% 10-20 aurreztera irits daiteke industria farmazeutikoa $[30,31]$.

\subsection{Medikamentuen bizi-ziklo osoan jardutea}

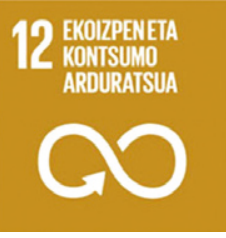

15 LEHORREKO

BIZIZA

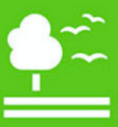

12.1. Kontsumo eta ekoizpen arduratsurako ekintzak

12.4. Hondakin eta produktu kimikoen kudeaketa

\subsection{Hondakinen prebentzio, murrizketa, birziklapena eta berrerabilera}

\subsection{Ekosistemak modu iraunkorrean erabili eta mantentzea}

Agenda 2030en helburuetako bat ekoizpen eta kontsumo iraunkor zein arduratsua da. 2007. urteaz geroztik lortutako datu batzuen arabera, Espainian pertsonako $186 \mathrm{~kg}$ hondakin sortzen ditugu medikamentuen ontziekin. Ondorioz, medikamentuen ekoizpen kimikoaz gain, medikamentuen ontzien ekoizpenak ere garrantzi handia du [33].

Medikamentuen ontzien ingurumen-analisia egiteko hainbat analisi-metodo erabil daitezke, baina ezagunena bizi-zikloaren analisia da 
(9. irudia). Medikamentuen ontzien bizi-zikloan ikusten den moduan, medikamentuen ontzi edo kutxak ekoizteko behar diren lehengaiak lortzen direnetik hondakinak kudeatu eta birziklatzen diren arte, hainbat etapatatik pasatzen da produktua. Horietan guztietan zenbait baliabide erabiltzen dira (energia, ura, lehengaiak), eta prozesu horretan zenbait hondakin-uretara, lurrera edo airera bideratzen dira. Hori dela eta, etapa hauetan gertatzen diren prozesu guztiek dute eragina ingurunean, eta GIH honek, ekoizpen eta kontsumo arduratsuak, erronka garrantzitsu bat proposatzen du: hemendik 2030era produktu kimikoak eta hondakin guztiak ekologikoki arrazoizkoa den moduren batean kudeatzea beren bizi-zikloan; horrekin batera, nabarmen murriztea atmosferara, uretara eta lurrera egiten dituzten isuriak, horiek giza osasunean eta ingurumenean dituzten eragin kaltegarriak arintze aldera (9. irudia) $[6,34]$.

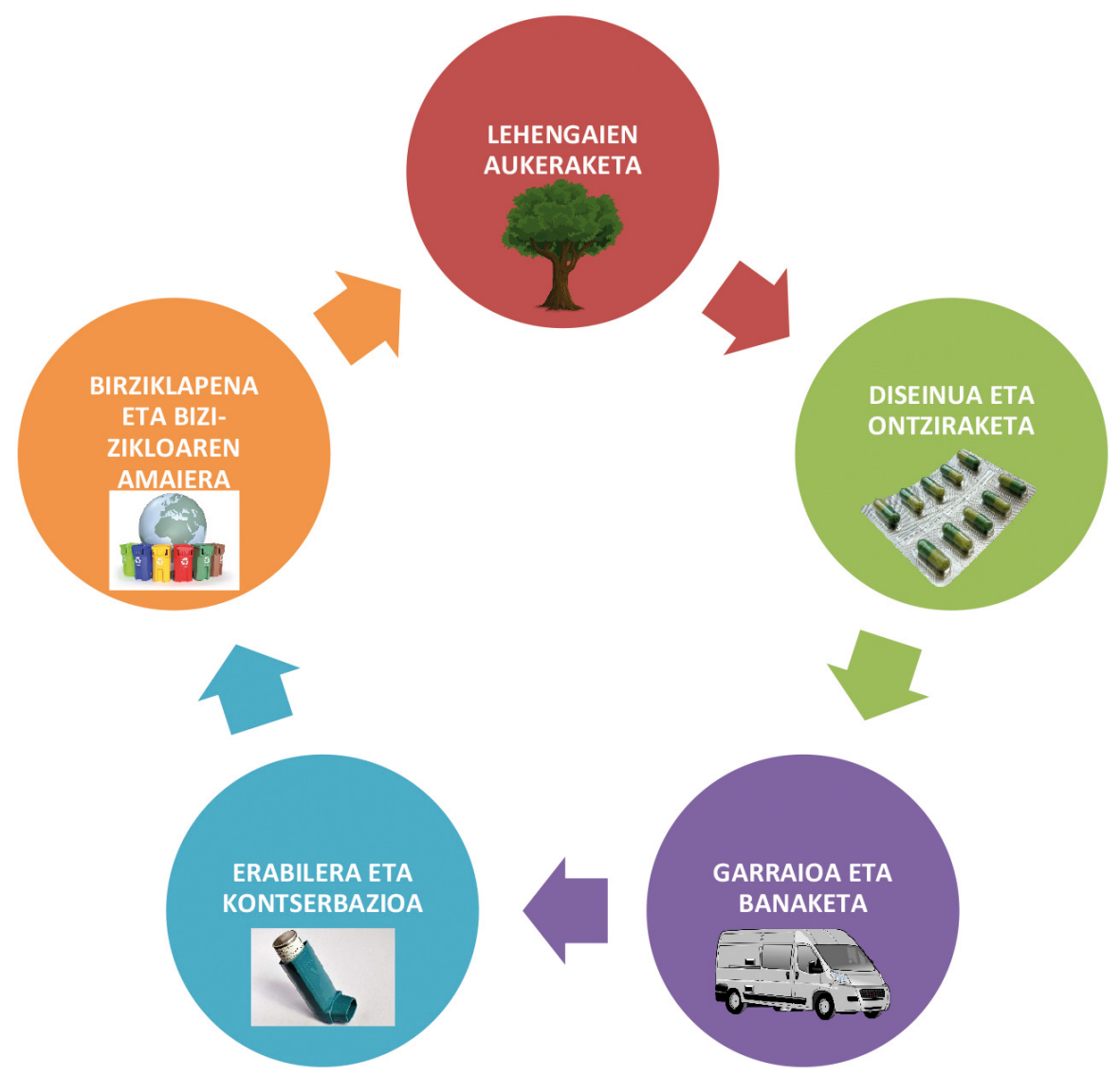

9. irudia. Medikamentuen kutxa edo ontzien bizi-zikloaren etapak [34]. 


\subsubsection{Lehengaien aukeraketa}

Medikamentuaren egokitzapena bi mailatan gauzatzen da, egokitzapen primarioa eta sekundarioa. Egokitzapen primarioa medikamentuarekin kontaktuan dagoen materiala da, eta zenbait ezaugarri izan behar ditu medikamentua hezetasunetik, tenperaturatik eta abarretik babesteko; eta normalean blisterrak, tapoiak, ontziak... izaten dira. Aldiz, medikamentuen egokitzapen sekundarioa kanpoan dagoen materiala da, eta normalean kartoizkoa izaten da. Haren funtzioa medikamentuari euskarri bat ematea izaten da, eta orobat oso garrantzitsua da prospektua gordetzeko. Kartoia zenbait papergeruzaz (paper birziklatuz normalean) osaturiko materiala da $[35,36]$.

Egokitzapenerako materialaren aukeraketak bere garrantzia dauka. Hortaz, medikamentuaren bizi-zikloko lehen pausoa lehengaien aukeraketa da, kutxak edo ontziak ekoizteko behar diren lehengaien aukeraketa, alegia. Beraz, kartoiaren gramajeak zein kartoi kantitateak berebiziko garrantzia dute.

Kartoi kantitatea murrizte aldera, kartoiaren gramajea murriztea litzateke aukera bat. Normalean 160 eta $600 \mathrm{~g} / \mathrm{m}^{2}$ bitartekoak izaten dira, baina $125 \mathrm{~g} / \mathrm{m}^{2}$ eta $130 \mathrm{~g} / \mathrm{m}^{2}$ bitartekoak erabil daitezke helburu hau betetzeko.

Kartoiaren kantitatea murrizteaz gain, oso garrantzitsua litzateke, baita ere, beharrezkoa ez den materiala saihestea. Zenbaitetan, medikamentuen ontziak zelofanarekin estalirik egoten dira, eta hori, beharrezkoa izan ezean, ez litzateke erabili behar. Zenbait pomada eta krema ere askotan plastikozko potetan etortzen dira, eta kanpotik kartoizko kutxa eramaten dute, prospektua gorde ahal izateko. Hori ahal den neurrian saihestea aukera bat litzateke, prospektua xarabearen potean bertan itsatsiz, adibidez [33, 34, 37]. Pauso horretan, komenigarria litzateke, baita ere, medikamentuen ontzien eta tapoien tamaina murriztea. Blisterren kasuan, ahalik eta gehien aprobetxatzea bilatuko litzateke, blister bateko leku guztia aprobetxatuz (10. irudia) [38].
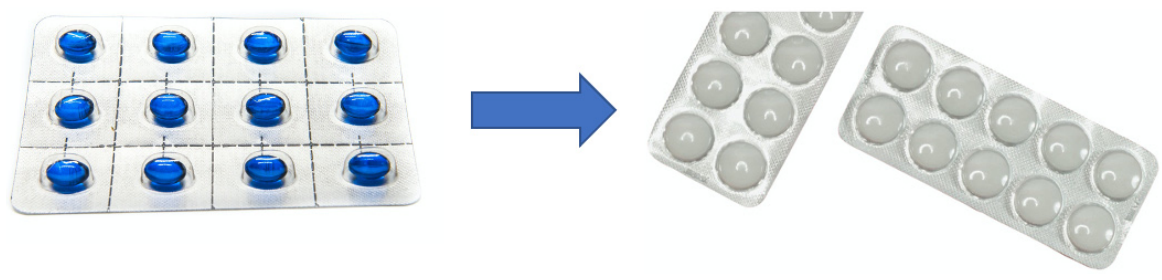

10. irudia. Blisterraren probetxu optimoa.

\subsubsection{Diseinua eta ontziraketa}

Diseinuari dagokionez, ontziaren diseinua optimizatuko litzateke; esaterako, xiringak dakartzaten medikamentuak asko dira, eta xiringak berak 
ontzian bertan instalaturik egongo balira, diseinua hobetuko litzateke, material gutxiago erabiliz (11. irudia). 2030 Agendari erreparaturi, diseinuaz gain ontziratzeak ere paper garrantzitsua dauka, eta ontziratze-prozesua azkartuko litzateke ontzien diametroa handituko bagenu [38].
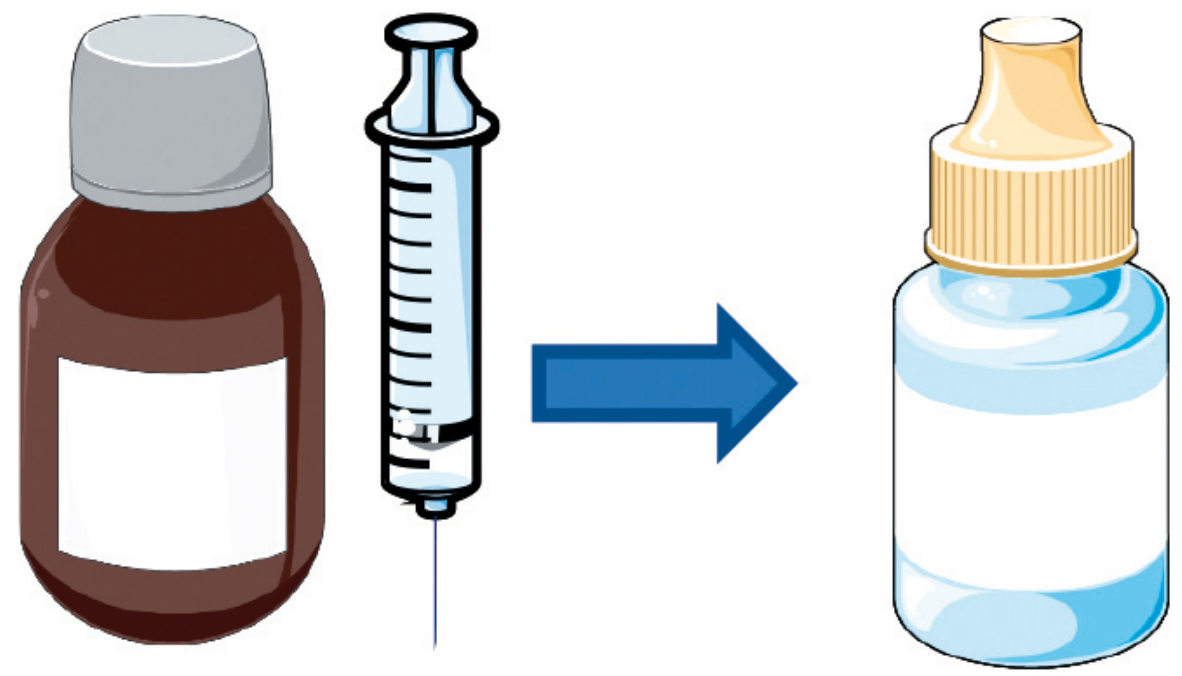

11. irudia. Ontziaren diseinua optimizatzeko modua [38].

\subsubsection{Garraioa eta banaketa}

Hurrengo etapa garraio eta banaketari dagokio. Hemen interesgarri litzateke bidaia iraunkorragoak egitea; hau da, ibilbideak aurrez ondo planifikatzea informatikaren laguntzaz, gasolina zein denbora aurrezteko. Gainera, 2030 Agendaren helburu garrantzizkoa dugu klima-aldaketaren aurrean neurri urgenteak hartzea eta, garraioa atmosferan askatzen den $\mathrm{CO}_{2}$-aren \%20-25 dela kontuan izanik, beharrezkoa litzateke, ahal den neurrian behintzat, $\mathrm{CO}_{2}$-aren isurtzea murriztea $[39,40]$.

Horretarako, garraiorako furgoneta elektrikoak erabiltzea estrategia egokia litzateke. Ibilgailu elektrikoek motor elektrikoa dute, eta bateria elektriko baten bidez higiarazten dira. Hortaz, industria farmazeutikoko instalazioetan aurretik aipatutako eguzki-panelak kokatuta izanik, energia berriztagarria izango genuke furgoneta elektrikoak kargatu ahal izateko. Gainera, energia berriztagarriak erabiltzen dituzten lurraldeetan, kotxe elektriko batek, errekuntzazko batek baino $\% 70 \mathrm{CO}_{2}$ gutxiago isurtzen duela frogatu zuten Cambridge Unibertsitatean egindako ikerketa batean. Ondorio horretara iristeko, ibilgailu elektrikoen bizi-ziklo guztia aztertu zuten, eta kotxe elektrikoak ingurumenerako onuragarriagoak direla on- 
dorioztatu. Gainera, zientzialari horiek lortu dituzten datuen arabera, uste dute 2050erako bi kotxetik bat elektrikoa izango dela, eta horrela munduko $\mathrm{CO}_{2}$-aren isurketa $1,5 \mathrm{Gt} /$ urte murriztuko dela [39].

\subsubsection{Kontserbazioa eta erabilera}

Kontserbazioari eta erabilerari dagokienez, administrazioa eta kontserbazioa optimizatzea litzateke urrats bat. Hori dela eta, produktuen erabilera ahalik eta gehien luzatzea garrantzitsua da, produktuen diseinuan jardunez, hau da, itxiera eta irekiera itzulgarria duten sistemak erabiliz. Adibidez, aerosoletan hezetasuna edo oxigenoa harrapatzen duten tapoiak erabiltzea aukera egokia litzateke [38].

\subsubsection{Bizi-zikloaren amaiera eta birziklapena}

2030 Agendak aipamena egiten dio birziklapenari; ekoizpen eta kontsumo arduratsuaren helburu horrek, hain zuzen, hemendik 2030era hondakinen sorrera murrizteko xedea du, eta horretarako birziklapena erabiltzea proposatzen du. Beraz, medikamentuak ekoizteaz gain, kontuan izan behar da ondoren medikamentu horiek birziklatzeak duen garrantzia. Medikamentuen kudeaketa-sistema integratuak (bere erdarazko laburdura, SIGRE) paper garrantzitsua du ingurumenean, medikamentuen kutxak eta gainerako hondakinek ingurumenean duten eragina murrizten baitu. Hobekuntza nabarmenak lortu ditu SIGREk; besteak beste, 2011n $\mathrm{CO}_{2}$-isurketa $116 \mathrm{kt}-$ murriztea lortu zuen (30 urtean 386.000 zuhaitzek askatutako $\mathrm{CO}_{2}$-aren baliokidea) eta 2018an medikamentuen kutxetako materialaren \% 62,34 birziklatzea [41,42].

SIGRE sektore farmazeutikoak sustatutako bilketa selektiborako sistema da, herritarrek etxeetan dituzten ontziak eta botika-hondarrak erraz eta eroso birzikla ditzaten. Horretarako, botikariek aholkatu, informatu eta herritarra animatzen dute botiken ontziak eta hondakinak farmazian dagoen SIGRE puntuan utz ditzan. Farmaziak herritarrengandik hurbil daudenez eta herritarrek farmazialariarengan duten konfiantzari esker, oso garrantzitsua da ingurumen-aholkularitza ematea. Beraz, oso garrantzitsua da pazientearen esku-hartzea, hau da, pazienteak berak ere industria farmazeutikoak sortzen duen kutsadura murrizten laguntzea SIGRE sistemaren bidez.

Industria farmazeutikoak, beraz, SIGREren sustatzailea izateaz gain, produktuaren garapenean funtzio bikoitza du: alde batetik, kutxa bakoitzeko kuota bat ordaintzen du SIGRE sistema bultzatzeko eta, bestetik, ingurumeneko inpaktua murrizteko kutxen ekodiseinua egiten du. Horrela, kutxa bakoitzaren pisua \% 22,85 murriztu da azken 10 urteetan [43]. 


\section{ONDORIOAK ETA ETORKIZUNEKO GOGOETA}

Industria farmazeutikoa indartzen ari den sektorea da. Populazioa handitzen den heinean, medikamentuen beharrak gora egingo du, eta, horrekin batera, ekoizpen farmazeutikoa ere handitu egingo da. Hori guztia, jasangarria izateko, etorkizun laburrean aurreikusten da medikamentuen ekoizpenaren arloan disolbatzaile organikoak ordezkatzea, eta ordezko gisa garrantzitsuak dira likido ionikoak zein fluido superkritikoak. Uraren argitzapenean, esaterako, fentonak eta antzeko oxidazio erreakzioek hartuko lukete lekua. Horrez gain, espero da industria farmazeutikoaren instalazioak energia berriztagarriz hornitu eta energiaren efizientzia hobetzen duten instalazioekin ekipatuta egotea. Hala ere, ekoizpenean ez ezik, medikamentuen bizi-ziklo osoan ere aurrerapenak espero dira.

Industria farmazeutikoa $\mathrm{I}+\mathrm{G}+\mathrm{b}-\mathrm{n}$ gehien inbertitzen duen sektorea da, eta nabarmen azken urteetan. Hain zuzen, 2017an Espainian 1.147 milioi euro inbertitu zituen $\mathrm{I}+\mathrm{G}+\mathrm{b}-\mathrm{n}$, industriako balio altuena eta aurreko urtekoa \% 5,7 handiagoa (1). Europa mailan ere, industria farmazeutikoak urtero 35.000 milioi euro inbertitzen ditu, eta azken urteetan balio horiek goraka doaz (orain azken 25 urteetan baino 4 aldiz gehiago inbertitzen du). Beraz, beste industria garrantzitsu batzuekin alderatzen badugu, lehenengo kokatzen da I+G+b-n; sektore aeronautikoak baino 2 aldiz gehiago inbertitzen du, eta sektore informatiko/elektronikoak baino 5 aldiz gehiago [1].

Etengabeko berrikuntzarako gaitasun horrek, agintariek bultzaturiko sustapen-neurri egokiekin batera, desiraturiko aldaketarako baliabideak eta tresnak jartzen ditu mahai gainean. Beraz, hurrengo urteak erabakigarriak izango dira industria hau hartzen ari den papererako. Baliabide eta tresna egokiak izanez gero, salto teknologiko garrantzitsua egingo genuke, bai eta iraultza berri honetan pausoa behar bezala eman ere.

\section{ESKER ONAK}

Egileek esker onak eman nahi dizkiete IdoFar hezkuntza berrikuntzarako taldeko kideei, lan honetan egindako ekarpen aberasgarriengatik.

\section{BIBLIOGRAFIA}

[1] La industria farmacéutica, un «Fórmula 1» para la economía y el empleo FarmaIndustria, https://www.farmaindustria.es/web/reportaje/la-industriafarmaceutica-un-formula-1-para-la-economia-y-el-empleo/ (2021eko apirilaren 21ean kontsultatua). 
[2] Arnold, K. E., Brown, A. R., Ankley, G. T., Sumpter, J. P. 2014. «Medicating the environment: assessing risks of pharmaceuticals to wildlife and ecosystems». Philosophical transactions of the Royal Society of London. Series B, Biological sciences, 369, 20130569.

[3] The environmental impact of pharmaceutical manufaturing: How does industry address its own wast.https://noharm-europe.org/sites/default/ files/documents files/5731/2018_PharmaceuticalIndustryReport_WEB. pdf (2021 eko apirilaren 21 ean kontsultatua).

[4] Pharma and the environment: why pollution remains a worrying trend, https://www.pharmaceutical-technology.com/features/pharma-and-the-environment-pollution-trend/ (2021 eko apirilaren 21ean kontsultatua).

[5] BelkhiR, L., Elmeligi, A. 2019. «Carbon footprint of the global pharmaceutical industry and relative impact of its major players». Journal of Cleaner Production, 214, 185-194.

[6] Objetivos y metas de desarrollo sostenible - Desarrollo Sostenible, https:// www.un.org/sustainabledevelopment/es/objetivos-de-desarrollo-sostenible/ (2021 eko apirilaren 21ean kontsultatua).

[7] ARECO, L. 2019. «Aplicaciones del $\mathrm{CO}_{2}$ supercrítico en procesos más sostenibles». Revista Cientifica OMNES, 11.

[8] Mestres, R. 2013. «Química Sostenible: Naturaleza, fines y ámbito». Educación Química, 24, 103-112.

[9] 2016. «ICH guideline Q3C (R6) on impurities: guideline for residual solvents». European Union News.

[10] Slater, C. S., Savelski, M. J., Hesketh, R. P., Frey, E. 2006. « The selection and reduction of organic solvents in pharmaceutical manufacture, paper 17 presented at the American Chemical Society 10th Green Chemistry and Engineering Conference ».

[11] 1,1,1-trichloroethane - Substance Information - ECHA, https:/echa.europa. eu/es/substance-information/-/substanceinfo/100.000.688 (2021eko apirilaren 21ean kontsultatua).

[12] IKEDA, M. 1992. «Public health problems of organic solvents». Toxicology Letters, 64, 191-201.

[13] Grodowska, K., Parczewski, A. 2010. «Organic solvents in the pharmaceutical industry». Acta Pol Pharm, 67, 3-12.

[14] David, R. M., Mecerreyes. 2005. «Liquidos iónicos: fascinantes compuestos para las quimica del siglo XXI». Anales de la Real Sociedad Española de Química, 22-28.

[15] LiU, R., Zhang, P., Zhang, S., Yan, T., Xin, J., Zhang, X. 2016. «Ionic liquids and supercritical carbon dioxide: green and alternative reaction media for chemical processes». Reviews in Chemical Engineering, 32, 587-609.

[16] Earle, M. J., Seddon, K. R. 2000. «Ionic liquids. Green solvents for the future». Pure and Applied Chemistry, 72, 1391-1398. 
[17] Sanz, J., Lombraña, J., Luis, A. 2013. «Estado del arte en la oxidación avanzada a efluentes industriales: nuevos desarrollos y futuras tendencias». Afinidad. Revista de química teórica y aplicada.

[18] OMS I Productos farmacéuticos en el agua potable, https://www.who.int/ water_sanitation_health/emerging/info_sheet_pharmaceuticals/es/ (2021eko apirilaren 21 ean kontsultatua).

[19] Rubio clemente, A. Chica, e. pañuelas Mesa G. «Aplicación del proceso Fenton en el tratamiento de aguas residuales de origen petroquímico». Ingeniería y Competitividad, 16, 211-223.

[20] Monge, Sra. S. B., Silva, Dr. A. M. T., BengoA, Dr. C. 2018. «Manual Técnico Sobre Procesos de Oxidación Avanzada Aplicados al Tratamiento de Aguas Residuales Industriales».

[21] Cambio climático - Desarrollo Sostenible, https://www.un.org/sustainabledevelopment/es/climate-change-2/ (2021eko apirilaren 21ean kontsultatua).

[22] DinCER, I. 2000. «Renewable energy and sustainable development: a crucial review». Renewable and Sustainable Energy Reviews, 4, 157-175.

[23] Gao, Z., Geng, Y., Wu, R., Chen, W., Wu, F., Tian, X. 2019. «Analysis of energy-related $\mathrm{CO}_{2}$ emissions in China's pharmaceutical industry and its driving forces». Journal of Cleaner Production, 223, 94-108.

[24] Funsho, M., Hizam, V., Pouresmaeil, E. 2010. «Distributed energy resources and benefits to the environment». Renewable and Sustainable Energy Reviews 724-734.

[25] La apuesta de la industria farmacéutica por la eficiencia energética - Revista Dyna Energía, https://www.dyna-energia.com/noticias-ES/la-apuesta-de-industria-farmaceutica-por-eficiencia-energetica (2021eko apirilaren 21ean kontsultatua).

[26] Energía solar, https://solar-energia.net/ (2021eko apirilaren 21 ean kontsultatua).

[27] Alcon obtiene el Premio Excelencia Energética - Acta Sanitaria, https:// www -actasanitaria.com/alcon-obtiene-el-premio-excelencia-energetica/ (2021eko apirilaren 21ean kontsultatua).

[28] Premio Excelencia Energética a Alcon por su trayectoria, https://www. europapress.es/epsocial/responsables/noticia-premio-excelencia-energeticaalcon-trayectoria-20160308135621.html (2021eko apirilaren 21 ean kontsultatua).

[29] Almirall construye la planta fotovoltaica de autoconsumo más grande de Cataluña | Tecnoenergía, https://profesionaleshoy.es/energia/2018/11/28/ almirall-construye-la-planta-fotovoltaica-de-autoconsumo-mas-grande-decataluna/11212 (2021eko apirilaren 21ean kontsultatua).

[30] Masanet, E. 2006. «Improving Energy Efficiency in Pharmaceutical Manufacturing Operations - Part I: Motors, Drives and Compressed Air Systems».

[31] Certificación: clave para optimizar el consumo energético de la industria farmacéutica I Tecnoenergía, https://profesionaleshoy.es/energia/2017/10/10/ 
certificacion-clave-para-optimizar-el-consumo-energetico-de-la-industriafarmaceutica/9307 (2021eko apirilaren 21ean kontsultatua).

[32] Serrano, A., IERz A., Martínez-Iturbe B, A. 2015. «Analysis of energy saving in industrial LED lighting». DYNA: revista de la Facultad de Minas, 82, 231-239.

[33] Martin, T. H. J. 2010. The European Environment. Publications Office, Luxembourg.

[34] Ecodiseño - SIGRE, http://www.sigre-ecodiseno.es/ (2021eko apirilaren 21ean kontsultatua).

[35] Pujol, A. 2016. «Papel y cartón "br"». Anales de la Literatura Española Contemporanea, $\mathbf{4 1}, 7$.

[36] Soriano, M. C., Sánchez-Lafuente, C., Alvarez-Fuentes, J., Holgado, M. A. 2000. «Acondicionamiento de medicamentos: funciones y tipos de envasado». Industria Farmacéutica, 3, 95-101.

[37] Bhargav, P. K. R. I DR. V. R. 2016. «A Study on Green Packaging-A Case Study Approach Withreference to Dell Inc». International Educational Scientific Research Journal, 2.

[38] Del Barrio, Y., Mampaso, J.C., «El Ecodiseño En Envases Farmacéuticos (SIGRE Medicamento y Medio Ambiente)».

[39] Knobloch, F., Hanssen, S. v, Lam2, 3. Aileen, Pollitt, H., Salas, P., Chewpreecha4, U., Huijbregts, M. A. J., Mercure, J.-F. 2020. «Net emission reductions from electric cars and heat pumps in 59 world regions over time». Nature sustainability, 3, 437-447

[40] Leduc, P., Dubar, B., Ranini, A., Monnier, G. 2003. «Downsizing of Gasoline Engine: an Efficient Way to Reduce $\mathrm{CO}_{2}$ Emissions». Oil \& Gas Science and Technology, 58, 115-127.

[41] Ferrão, P., Ribeiro, P., Rodrigues, J., Marques, A., Preto, M., Amaral, M., Domingos, T., Lopes, A., E. InÊS CostA. 2014. «Environmental, economic and social costs and benefits of a packaging waste management system: A Portuguese case study». Resources, Conservation \& Recycling, 85, 67-78.

[42] El papel de los laboratorios en el medioambiente, https://www.sigre.es/laboratorios/ (2021eko apirilaren 21ean kontsultatua).

[43] SIGRE Publica su Memoria de Sostenibilidad 2018, https://www.sigre.es/ wp-content/uploads/2019/07/SIGRE-Memoria-de-Sotenibilidad-2018.pdf (2021eko apirilaren 21ean kontsultatua). 